PAEDAGogia CHRISTIANA

$1 / 25$ (2010) - ISSN 1505-6872

\author{
Monika Sztamborska* \\ Toruń
}

\title{
Dialogi o Bogu we wspólczesnej kulturze Colloquia Torunensia XIV, Toruń, 8 listopada 2008 roku
}

8 listopada 2008 roku w toruńskim Dworze Artusa odbyło się spotkanie z cyklu Colloquia Torunensia. Nawiązuje ono do Colloqium Charitativum - zjazdu katolików, luteran i kalwinów w 1645 roku w Toruniu, mającego na celu wprowadzenie pokoju religijnego. Tegoroczna sesja została zatytułowana: Dialogi o Bogu we wspótczesnej kulturze. Poprowadził ją ks. prof. dr hab. Jerzy Bagrowicz, który podkreślił potrzebę podejmowania rozmów o Bogu w każdym obszarze kultury. Stwierdził, że alternatywą dialogu jest niezrozumienie, izolacja, co w konsekwencji może doprowadzić do przemocy. Dlatego uczestnikami rozmów o Bogu są nie tylko ludzie wierzący, ale również poszukujący sensu egzystencjalnego. Pragnienie Absolutu nie zginęło z naszych umysłów, dlatego dialogi o Bogu we współczesnej kulturze są pełne pasji i zaangażowania. Jak co roku, komitet organizacyjny Colloquia Torunensia stanowili: Prezydent Miasta Torunia, Biskup Toruński, Rektor Uniwersytetu Mikołaj Kopernika w Toruniu oraz Prezes Towarzystwa Naukowego w Toruniu.

Tegoroczne spotkanie rozpoczął prof. dr hab. Marek Szulakiewicz wykładem z zakresu z filozofii religii pod tytułem: Bóg dzisiaj. Jak mówić współczesnemu człowiekowi o Bogu? Na wstępie Prelegent powiedział, że XXI wiek będzie wiekiem religii. Jako przesłanki tej tezy podał między innymi zmierzch ery sekularyzacji, postęp w nauce, odejście od traktowania religii jako alternatywy dla nauki, kultury, filozofii oraz uznanie religii za próbę zrozumienia świata. Filozof postawił pytanie: „Czy warto mówić

* Mgr Monika Sztamborska, absolwentka pedagogiki na Wydziale Nauk Pedagogicznych UMK w Toruniu, studentka V roku historii na Wydziale Nauk Historycznych UMK. 
o Bogu dzisiaj?" Podkreślił, że słowa nie tylko przedstawiają rzeczywistość, ale moga ją również fałszować. A na milczenie o Bogu może mieć wpływ Jego tajemniczość oraz ograniczenia poznawcze człowieka. Mówienie o Bogu jest niepewne, a przede wszystkim historyczne i dziejowe, dlatego każda epoka jest zaangażowana w odkrywanie prawdy o Bogu. Profesor zauważył, że na rozmowy o Bogu wpływają konteksty historyczno-kulturowe. Egzemplifikacją tego jest chrześcijańska doktryna o Stwórcy, wywodząca się z tradycji biblijnej oraz filozofii grecko-rzymskiej. To właśnie z greckiej kultury wypływa pojmowanie Boga jako najdoskonalszego bytu. Implikowało to pojmowanie Boga jako „dokończonego" i „zamkniętego”. Profesor Marek Szulakiewicz wskazał, że należy odrzucić metafizyczne myślenie, gdyż prowadzi ono do błędów idolatrii. Postawił również pytanie: „Jak mówić o Bogu dzisiaj?" Nadmienił, że pluralizm kulturowy i religijny, w jakim żyjemy, wzywa każdego do otwarcia się na kontekstualność wiary, wielość religii i odrzucenie teologicznego absolutyzmu. Współczesne mówienie o Bogu rodzi się w dialogu z nowym światem i religiami. Prelegent podkreślił, że należy mówić o Bogu tak, żeby zostawić zawsze miejsce na ,jeszcze inaczej”. Mowa o Bogu wymaga przemiany w mowę „do Boga”. Filozof podkreślił, że współczesny człowiek potrzebuje nie Boga, o którym się mówi, lecz Boga, do którego się mówi. Powiedział też, że mówienie o Bogu powinno prowadzić nie do wiedzy i panowania, lecz do zawierzenia i nadziei.

W kolejnym referacie pod tytułem: Natura jako norma w sporze o przyszłość ludzkiej kondycji, siostra prof. dr hab. Barbara Chyrowicz podjęła problem granic dopuszczalności modyfikowania ludzkiej natury. Wprowadzając w temat, przytoczyła wizję biofizyka Gregory Stocka, który twierdzi, iż w przyszłości metaczłowiek będzie modyfikował własną naturę. Wpłynie to na zmianę pojęcia człowieka, który, według Stocka, będzie istotą po części biologiczną, mechaniczną i elektroniczną. W dalszej części referatu prelegentka przytoczyła wizję przyszłości, stworzoną przez Lee M. Silvera. Według niego, w 2350 roku wzbogacona genetycznie nowa rasa „GenRich” stanowić będzie około 10\% ludności. Genetyczna arystokracja będzie miała kontrolę nad gospodarką, środkami masowego przekazu i przemysłem rozrywkowym, a pozostała ludność będzie wykonywała nisko płatne prace usługowe lub fizyczne. Następnie siostra Chyrowicz zaprezentowała obawy, jakie towarzyszą biotechnologicznym fascynacjom oraz postawiła pytanie o granice dopuszczalnych ingerencji w ludzką naturę. To właśnie one mogą być podstawą moralnego wartościowania zmian w ludzkim genomie. Zaznaczyła, że „nienaturalny” nie musi od razu oznaczać „moralnie niedopuszczalny”, a naturalny - „moralnie dopuszczalny”. Nienaturalne są przecież antybiotyki, endoprotezy i przeszczepy organów, natomiast naturalny 
jest rozwój choroby nowotworowej oraz wszelkie obciążenia genetyczne. Przed bioetyką stoi zadanie ustalania norm, według których ingerowanie w ludzką naturę może być słuszne lub niedopuszczalne. Barbara Chyrowicz wspomniała o specyfice posiadania ludzkiej natury, która wyraża się tym, że cokolwiek dzieje się z ludzkim ciałem, dzieje się jednocześnie z osobą. Jednak biotechnologiczna rewolucja, umożliwiająca kontrolę własnego gatunku, wpływa na sposób traktowania przez człowieka swojej cielesności, która coraz bardziej przestaje być czymś integralnym z człowiekiem, a staje się „czymś obok”. Podsumowaniem referatu było stwierdzenie, że natura może stanowić punkt odniesienia $\mathrm{w}$ dyskusji z ideami posthumanizmu jedynie wtedy, gdy w bioetyce przyzna się miejsce przesłankom antropologicznym i gdy naturę ludzką uzna się za niezmienną wartość.

Kolejny wykład pod tytułem: Współcześni uczeni w rozmowie o Bogu wygłosił ks. prof. dr hab. Stanisław Kowalczyk. Przedstawił problematykę Boga na pograniczu nauk empiryczno-przyrodniczych i filozoficznych. Zaprezentował różne stanowiska, dotyczące mówienia o Bogu w oparciu o nauki przyrodnicze, i stosunek do tego zagadnienia filozofów klasycznych. Szczególnym przykładem są poglądy tomistów, którzy podkreślają odrębność metod badawczych nauk przyrodniczych i filozoficznych. Prelegent przytoczył myśl Jana Pawła II, że nauka musi uznać swoje ograniczenia w dotarciu do Boga i nie jest w stanie potwierdzić ani zanegować Jego istnienia. W dalszej części referatu filozof zaprezentował ateistyczne postawy naukowców, a wśród nich Bertranda Russella, który był rzecznikiem ateizmu scjentystyczno-metodologicznego i polemizował z argumentami filozofii klasycznej na istnienie Boga. Stanisław Kowalczyk przedstawił również poglądy Jacquesa Monoda, głoszącego w latach 70. XX wieku, że cała przyroda, łącznie z człowiekiem, jest przypadkowym produktem ślepych sił natury. Obok ateistycznych idei Jacquesa Lacana i Richarda Rorty'ego Profesor przytoczył również myśli Richarda Dawkinsa - autora książki pod tytułem: Bóg urojony. W dalszej części wystapienia Filozof udzielił głosu naukowcom, między innymi: A. Eddingtonowi, J. Jeansowi i E. Whittakerowi, którzy przypisywali Bogu aktywną twórczość w powstaniu i zapoczątkowaniu kosmosu. Następnie zaprezentował poglądy Alfreda Whiteheada, który próbował połączyć chrześcijaństwo ze współczesnymi naukami przyrodniczymi. Jednak głosząc, że Bóg stwarza świat i że świat stwarza Boga, nie spostrzegł, iż skoro Bóg powstaje ze światem i dzięki niemu, to nie może pełnić funkcji sprawczo-twórczej. W końcowej części referatu prelegent przeszedł do omawiania rozważań o Bogu na gruncie dociekań filozoficznych. Mówił, że filozofia klasyczna wysuwa dwa typy argumentacji za istnieniem Boga: ontologiczno-kosmologiczny oraz antropologiczno-aksjologiczny. Pierwszy z nich odwołuje się do doświadczenia zewnętrznego i bazuje na poglądach 
św. Tomasza z Akwinu. Natomiast drugi nawiązuje do sfery wewnętrznopersonalnej człowieka, jego myśli, poznawalności, prawdy, sumienia i doświadczenia religijnego. Nurt ten prezentują idee św. Augustyna, Jacquesa Maritaina, Henri Bergsona i Maxa Schelera.

Ostatni referat został przedstawiony przez Wacława Oszajcę, który nadał mu tytuł: Bóg współczesnych poetów. Za wyznacznik współczesności Jezuita uznał II wojnę światową. Stwierdził, iż jest tak ważnym wydarzeniem, że wprawia w zakłopotanie zarówno kapłana, jak i filozofa. Porównał poetę do mistyka, który przerzuca mosty z jednego brzegu rzeczywistości na drugi. Podkreślił, że zarówno dla mistyka, jak i poety-mistyka, poezja nie jest ułuda, czczą gadanina, ale metodami opisywania i poznawania rzeczywistości. Przytoczony wiersz Tadeusza Różewicza: Przepisałem dnia 7 lutego 1988 roku, opisuje pulsujące życie i śmierć, która jest jego przedłużeniem. W kolejnym utworze, autorstwa Davida H. Lawrence'a, pod tytułem: Ryba, prelegent zauważył związek Boga-Stwórcy ze stworzeniem. Powiedział, że jest to zjednoczenie, o którym nie można pomyśleć, że może ustać, tak jak niemożliwe jest życie ryby bez wody. Kontynuując swoją myśl, Wacław Oszajca podkreślił, iż nie można pomyśleć człowieka bez Boga, ale i Boga bez człowieka, bo związek miedzy nimi jest sakramentalny, transcendentalny i ontyczny. Interpretując wiersz Zbigniewa Herberta pod tytułem: Glos, Referent powiedział, że niedoskonałość naszego poznawania świata może wtrącać człowieka w rozpacz, ale nigdy w bierność. Podkreślił, że trzeba nadal poszukiwać, wsłuchiwać się w głos świata i czuwać, by nie ulec złudzeniu i nie pomylić głosów. Przywołani poeci nie szukają Boga w idealnej transcendencji, w niebie, ale również w słabości i grzechu człowieka, co obrazuje wiersz Jaroslava Seiferta pod tytułem: Matka Boska Żyżkowska. Strach przed utratą szczęścia odarł z pychy młodego poetę, który zrozumiał, że nie wszystko zależy od niego. Jego słabość stała się asumptem zwrócenia się ku Bogu. Wacław Oszajca podsumowując podkreślił, że bez wiary i bez nadziei można się obyć, można po ludzku żyć i umierać, nie można natomiast żyć bez miłości.

Podsumowania XIV sesji obrad Colloquia Torunensia, odbywającej się pod hasłem: Dialogi o Bogu we wspótczesnej kulturze, dokonał ks. prof. Jerzy Bagrowicz. Nawiązując do wystapienia Stanisława Kowalczyka, przytoczył stwierdzenia Jacques'a Maritaina, że nauki przyrodnicze, mimo iż nie są w stanie potwierdzić ani zaprzeczyć istnieniu Boga, są Jego świadkiem. Po pierwsze, dlatego że nauki przyrodnicze - odkrywając prawa rządzące przyrodą - potwierdzają jej racjonalność i bytową sensowność, a po drugie, ludzki intelekt jawi się jako natura, która nie może być wytworem materii i dlatego wskazuje na obecność absolutnej Myśli - Boga. Jerzy Bagrowicz podkreślił, że współczesne rozmowy o Bogu toczą się w kontekście trud- 
nych doświadczeń XX wieku, pełnego zbrodni na skalę światową. Wobec tego pojawia się pytanie, jak mówić współczesnemu człowiekowi o Bogu. Na potrzebę poszukiwania nowych sposobów mówienia o Bogu wskazał w swoim referacie profesor Marek Szulakiewicz. Powiedział, że człowiek nieprzygotowany do mówienia o Bogu jest skłonny popaść w bałwochwalstwo. Postulował również, aby mowę o Bogu zmienić w mowę do Boga. Jerzy Bagrowicz stwierdził również, że pytanie o Boga jest pytaniem o człowieka. Dlatego tak ważne są dywagacje na jego temat. Podjęła je siostra Barbara Chyrowicz, która przedstawiła różne wizje przyszłości ludzkiego genomu oraz pilną potrzebę ustalenia granic ingerencji w ludzką naturę. $\mathrm{Na}$ Colloquiach nie zabrakło poezji mówiącej o Bogu. Wacław Oszajca interpretując wiersze wskazał, że Bóg poetów to nie tylko Bóg filozofów, uczonych, ale Bóg Biblii, Bóg bliski każdemu człowiekowi, a w szczególności najsłabszemu.

Toruńskie spotkanie było bardzo bogate w różnorodną tematykę. Począwszy od dywagacji na temat, jak mówić współczesnemu człowiekowi o Bogu, poprzez rozważania ponowoczesnej bioetyki i poglądy współczesnych uczonych na temat Absolutu, aż po poezję, wskazującą na Boga. Colloquia Torunensia są jedynie asumptem do dalszych dialogów w każdej dziedzinie współczesnej kultury. 
